\title{
Herbert W. Basser and Marsha Cohen The Gospel of Matthew and Judaic Traditions: A Relevance-based Commentary
} (Leiden: Brill, 2015), xxii + 794 pp.

\author{
PETER ZAAS \\ zaas@siena.edu \\ Siena College, Loudonville, NY 12211
}

For the sake of full disclosure, I should begin with a few words about the oddity of this reviewer's position. This substantial volume (794 pp.) begins by quoting from a review I wrote of an earlier book by Basser. I stated that some readers might find his thought processes difficult to fathom, but I strongly encouraged them to nonetheless study his book. Inasmuch as I now expect some snippet of this review to find its way into his next volume, I write with Basser's future readers looking over my shoulder, which is an odd feeling. Also, I should note that Basser uses my translation of Matthew's Gospel as his main English text, with proper attribution.

Before discussing the content, it is necessary to comment on the authorship of the volume. The cover and title page (and Library of Congress listing) read "Herbert W. Basser with Marsha B. Cohen." In the preface written by Basser alone, he describes Cohen as a "co-author" and "more than a mere proofreader" (p. xvii). Despite his high praise for her intellectual and literary gifts, he then describes her actual work as mainly editorial, such as helping him organize his writing, especially in his comments to the latter half of the Gospel, by suggesting places he might be clearer or provide more definite examples. This volume is a contribution to Basser's field, rabbinic Judaism. Cohen is an independent scholar with a Ph.D. in international relations. Without belittling her contribution to this volume in any way, I here follow Basser's lead. He refers to the author of this volume in the first person singular ("I"), and I shall refer to that author in the third person singular ("Basser"). The volume is well-organized and gracefully written, and for some of that we must surely owe substantial thanks to Cohen. (For a New Testament scholar, this topic of authorship is reminiscent of questions regarding multiple authorship of some of Paul's letters: How much is written by Paul? How much by Silas or Timothy?)

Attempts to characterize Herbert Basser's methodology of drawing connections between New Testament and rabbinic texts is practically an academic subgenre. Nearly all of those who have written critically of this methodology have immense respect for his encyclopedic knowledge of rabbinic texts, and also his 
extraordinary literary sensitivity. No one has a greater feel for the poetic nuances of rabbinic language, and Basser's conclusions are worth considering no matter whether one thinks he is being methodologically consistent. This is the greatest value of a Basser volume, evident in his previous study of Matthew 1-14, The Mind Behind the Gospels (Boston: Academic Studies Press, 2009). Compared to Strack-Billerbeck, whose Kommentar zum Neuen Testament aus Talmud und Midrasch he intends to supplant, Basser adds dimensionality to the parallels he adduces by considering their relevance to the study of Matthew. He transcends Strack-Billerbeck's mainly unadorned listing of similarities between New Testament and Rabbinic texts, a methodology that Samuel Sandmel called "parallelomania." It might be best to describe both of Basser's Matthew volumes as imaginative attempts to put the text of the First Gospel into conversation with the classical literature of Judaism. That description might put them into the same category as Bruce Chilton's Rabbi Jesus and Rabbi Paul, which reflects both a fertile imagination and an extraordinary grasp of the available textual evidence.

The book is too large to review in detail, and some general comments will have to suffice. Basser structures his book, as he did The Mind Behind the Gospels, as a commentary. Moving chapter by chapter and verse by verse, he imaginatively presents Matthew as a sort of dialogue-partner with Rabbinic Judaism. This dialogue is constructed around an astounding range of sources that offer relevant parallels to the Gospel, taken from the Hebrew Bible (including every biblical book but Proverbs, Obadiah, Zephaniah, and Haggai) and rabbinic texts (an astounding range and depth from Mishnaic, Talmudic, Midrashic, Targumic, and even mystical sources, including two citations from the Zohar and one from Sefer Yetzirah). Basser puts Matthew in dialogue with everyone from Simeon the Righteous to Maimonides and beyond, a span of at least 1500 years.

Mainstream scholars of Matthew who use a redaction-critical methodology for study of the Gospel - this reviewer included-will wonder how to draw upon Basser's insights. Where most Matthew scholars see Matthew as supplementing the Gospel of Mark with the Q source and his own material, Basser says Matthew "originated from an older tradition no longer known" (p. 14). Matthew himself "was a gifted writer who interpolated his own ideas into the received narratives into his Gospel," following the artful process of "True storytellers [who] never tell, [but rather] show," leaving their readers "to draw conclusions based upon the descriptive images the storyteller evokes" (p. 15). The Evangelist's approach, in other words, rather resembles Basser's own; he sets an imagined Matthew in dialogue with the rabbinic corpus. This approach aims to show that whatever Matthew's messianic beliefs, he inhabits the same world of image and thought of many of the rabbinic sages and their spiritual and literary successors.

The approach has some drawbacks. Basser is largely unconcerned with the historical settings of both the Gospel and the rabbinic corpus. He puts a timeless Matthew in dialogue with timeless rabbis, without considering such issues as historical development. He precludes any possibility of Matthean influence on rabbinic views, since Matthew cannot influence views that always existed. Even if, for example, Matthew's views of Jewish marriage law seem to reflect Tannait- 
ic, as opposed to biblical, views, Basser precludes the possibility that Matthew could either have influenced rabbinic jurisprudence or reflects a pre-rabbinic view. Was it really always the law that a betrothal constituted a legal marriage and could only be dissolved with a get? (p. 37). In other words, such a historical question of where Matthew fits in the evolution of Jewish law is ignored by Basser. On the other hand, Basser masterfully presents a treasury of sources and resources, demonstrating areas where Matthew's views parallel those found in non-Christian Jewish sources. Matthew would have greatly enjoyed participating in the table-talk at a heavenly rabbinic symposium, if the rabbis would have been willing to invite him. Most scholars will find new insights here, and probably most scholars will also be annoyed at Basser's failure to integrate his views into some kind of historical framework.

In our time, we are blessed with an elevated level of interest in New Testament sources by self-identifying Orthodox Jews who are good (or great) textual scholars, Amy-Jill Levine their current doyenne, with Zev Garber and Herbert Basser nearly as prominent. Such scholars bring together seriousness about living Judaism and a mastery of traditional Jewish discourse (aggadic, halachic, mystical, and ethical), although of course Jewish Orthodoxy is by no means a prerequisite for the mastery of traditional texts, nor do all of these scholars bring the same presuppositions to their scholarship. Herbert Basser has been forthright about his own assumptions in the various projects that have made his work known among scholars of Second-Temple Judaism and its various aftermaths. It would be a good thing if his work were better-known among a wider circle. I myself enjoy the frustration of trying to fit his insights into the scholarly categories I find congenial. An annotated and highlighted copy The Gospel of Matthew and Judaic Traditions should be on everyone's shelf. 